\title{
Natural killer cells in human autoimmune disorders
}

\author{
Leslie A Fogel', Wayne M Yokoyama² and Anthony R French*1
}

\begin{abstract}
Natural killer (NK) cells are innate lymphocytes that play a critical role in early host defense against viruses. Through their cytolytic capacity and generation of cytokines and chemokines, NK cells modulate the activity of other components of the innate and adaptive immune systems and have been implicated in the initiation or maintenance of autoimmune responses. This review focuses on recent research elucidating a potential immunoregulatory role for NK cells in T-cell and B-cell-mediated autoimmune disorders in humans, with a particular focus on multiple sclerosis, rheumatoid arthritis, and systemic lupus erythematous. A better understanding of the contributions of NK cells to the development of autoimmunity may lead to novel therapeutic targets in these diseases.
\end{abstract}

\section{Introduction}

Autoimmune diseases exert a large burden on humanity. In 2005, the National Institutes of Health National Institute of Allergy and Infectious Diseases estimated that autoimmune disorders affected 24 million Americans [1]. A more recent estimate by the American Autoimmune Related Diseases Association utilizing a more comprehensive list of autoimmune diseases suggested that up to 50 million Americans (nearly one in six) are afflicted by an autoimmune disorder [2]. Although these disorders are primarily mediated by $\mathrm{T}$ cells and $\mathrm{B}$ cells, natural killer (NK) cells have been implicated in the induction and/or persistence of inappropriate adaptive immune responses in autoimmune diseases. A more complete characterization of the role of NK cells in human autoimmunity may lead to new therapies in these diseases.

${ }^{*}$ Correspondence: french_a@kids.wustl.edu

'Division of Pediatric Rheumatology, Department of Pediatrics, Washington University, Box 8208, 660 South Euclid Avenue, St Louis, MO 63110, USA Full list of author information is available at the end of the article
NK cells are granular, innate lymphocytes that do not express rearranged antigen receptors [3]. In humans, these CD3-negative lymphocytes are identified by the expression of CD16 and CD56, although recent studies have suggested that NKp46 (NCR1) may be an alternative marker [4]. NK cells comprise 5 to $15 \%$ of the peripheral blood mononuclear cells and are also found in secondary lymphoid tissues (for example, spleen, lymph nodes, and tonsils) as well as other organs such as the liver, intestine, skin, and lung [5]. In these various locations, NK cells function as innate sentinels and play a critical role in early immune responses to intracellular pathogens. In addition, NK cells are particularly abundant in the endometrium of the pregnant uterus where they influence the implantation of the embryo and the vascular function and formation of the placenta $[6,7]$.

Human NK cells can be divided into two major subsets based on the expression of CD56 [8]. CD56 ${ }^{\mathrm{dim}}$ NK cells comprise approximately $90 \%$ of circulating peripheral NK cells and express high levels of CD16, inhibitory killer immunoglobulin-like receptors (KIRs), and perforin (a pore-forming component in NK cell cytolytic granules) [9]. In contrast, CD56 $6^{\text {bright }} \mathrm{NK}$ cells are more abundant than CD56 $6^{\mathrm{dim}}$ NK cells in secondary lymphoid tissues such as lymph nodes and tonsils [10]. CD56 $6^{\text {bright }}$ NK cells express low levels of CD16, KIRs, and perforin, with higher expression levels of a number of cytokine receptors and CD94/NKG2A than CD56 ${ }^{\text {dim }}$ NK cells. The functional consequence of these differences (as well as differences in chemokine receptor expression) is that CD56 ${ }^{\text {bright }} \mathrm{NK}$ cells in secondary lymph organs are more efficient cytokine and chemokine producers while CD56 dim NK cells in the periphery are more potent cytolytic effectors. Furthermore, the differential expression of cytokine receptors by these two subsets allows the local microenvironment and inflammatory milieu to influence NK cell functional responses.

\section{Regulation of natural killer cell activation and licensing}

Individual NK cells express a variable number of germline encoded inhibitory and activating cell-surface receptors. The inhibitory NK cell receptors recognize either 
classical or nonclassical major histocompatibility complex (MHC) class I proteins, which in humans are encoded by the human leukocyte antigen (HLA) genes. For example, KIR3DL1 binds the classical MHC class I protein HLA-Bw4 [11,12] while CD94/NKG2A binds the nonclassical MHC class I protein HLA-E [13-15]. Some activation receptors recognize the same or similar ligands as inhibitory receptors (for example, both the inhibitory CD94/NKG2A and the activating CD94/NKG2C can bind to HLA-E $[13,14])$, while others recognize molecules with MHC class I structural folds that are upregulated by cellular stress (for example, NKG2D binds to MHC class I polypeptide-related sequence A [16]) or proteins encoded by pathogens (for example, NKp46 binds to influenza hemagglutinin [17]).

NK cell responses are determined by the integration of signals from these inhibitory and activating cell-surface receptors, although the activation threshold in NK cells is also influenced by cytokine stimulation [3]. NK cell responses are primarily restrained by inhibitory receptor recognition of ubiquitously expressed MHC class I ligands on host cells. However, NK cells are freed from this inhibition and have a lower activation threshold when infected or transformed cells downregulate MHC class I molecules under selective pressure to evade lysis by CD8 cytotoxic $\mathrm{T}$ cells (missing-self hypothesis) $[18,19]$. Furthermore, the upregulation of NK cell activation ligands on host cells is limited in the absence of cellular stress or infection [20,21] to minimize inadvertent NK cell activation and host damage.

Inappropriate NK cell activation is also prevented by NK cell licensing (reviewed in [22,23]). Although missing-self recognition is a well-established paradigm of NK cell activation, NK cells from MHC class I-deficient hosts are paradoxically less reactive to stimuli than cells from MHC class I-sufficient hosts [24]. Furthermore, NK cells that do not express a self-MHC-specific inhibitory receptor are hyporesponsive rather than hyperactivated [25-27]. These observations are explained by the recent concept of NK cell licensing which proposes that inhibitory NK cell receptor recognition of self-MHC class I is required for NK cells to become fully responsive to future stimulation through their activation receptors [27-29]. Although this hypothesis was initially described in murine systems [27], it has subsequently been validated in humans as well $[25,30]$. For example, when stimulated with MHC-deficient tumors, KIR3DL1-expressing NK cells generated substantial amounts of IFN $\gamma$ if the donor was homozygous for the KIR3DL1 ligand (HLA-Bw4); however, KIR3DL1expressing NK cells from donors that did not express HLA-Bw4 did not produce IFNy following similar stimulation [30]. Potential autoreactivity of unlicensed NK cells is therefore prevented by their hyporesponsiveness to stimulation through activation receptors.
In summary, NK cell activation is regulated through several distinct mechanisms to prevent inappropriate responses. First, NK cells express inhibitory receptors that recognize widely expressed ligands. Second, the upregulation of host ligands for activating receptors is regulated to prevent inadvertent damage to normal healthy tissues. Finally, full NK cell responsiveness requires licensing through inhibitory receptors, which prevents the unrestrained activation of NK cells that do not express appropriate self-MHC class I-reactive inhibitory receptors.

\section{Natural killer cells and immunoregulation}

The ability of NK cells to kill cells and release immunomodulatory cytokines and chemokines allows NK cells to modulate the innate immune response and mold the development of the adaptive immune response. For example, human NK cells promote dendritic cell (DC) maturation and DC production of cytokines such as TNF $\alpha$ and IL-12 [31-33]. Interestingly, NK cells can kill immature DCs, while mature DCs are resistant to killing as a result of their upregulation of MHC class I molecules $[34,35]$. Cytokine-activated human NK cells can also directly kill both activated macrophages [36] and $\mathrm{T}$ cells $[37,38]$ secondary to the upregulation of NKG2D ligands on these cells. NK cells are also able to provide costimulatory signals for CD4 $\mathrm{T}$ cells and augment their proliferation [39]. Additionally, NK cell-derived cytokines (including IFN $\gamma$ [9] and IL-10 [40-42]) influence the differentiation $[43,44]$ and the proliferation of CD4 T cells [42].

Impaired NK cell functional responses are frequently observed in patients with autoimmune disorders (discussed below). The importance of NK cell cytolytic function in immunoregulation is highlighted in hemophagocytic lymphohistiocytosis, a life-threatening disorder with uncontrolled immune activation and excessive T-cell production of cytokines leading to unrelenting phagocyte activation. This disorder results from a failure of cytolytic lymphocytes (CD8 T cells and NK cells) to kill infected cells and/or persistently activated $\mathrm{T}$ cells $[45,46]$. Patients with hemophagocytic lymphohistiocytosis uniformly have decreased NK cell cytolytic responses. Mutations in several proteins required for cytolytic granule release or function have been identified in hemophagocytic lymphohistiocytosis, including perforin, MUNC13-4, syntaxin 11, and syntaxin binding protein 2 (STXBP2) $[45,46]$. Mutations in STXBP2 directly implicate defective NK cell cytolysis in this disorder since STXBP2 expression is substantially higher in NK cells than in CD8 $\mathrm{T}$ cells and defects in degranulation have been observed in STXBP2-deficient NK cells but not in STXBP2-deficient CD8 T cells [47]. As illustrated by hemophagocytic lymphohistiocytosis, NK cell functional 
responses must be carefully regulated to prevent damage to normal tissues or dysregulation of the adaptive immune responses (for example, dsyfunctional cytolysis resulting in persistent T-cell and macrophage activation or indiscriminate release of IFNY resulting in inappropriate immune activation).

\section{Natural killer cell abnormalities in human autoimmune diseases}

Over the last 30 years, many studies have reported decreased NK cell numbers or impairment of NK cell cytotoxicity in the peripheral blood of patients with autoimmune diseases such as multiple sclerosis (MS), rheumatoid arthritis (RA), systemic lupus erythematosus (SLE), Sjögren's syndrome, and type I diabetes mellitus (T1DM) (reviewed in [48-54]). Although some of the older reports did not distinguish between NK cells and NKT cells ( $T$ cells with NK cell markers, typically restricted by $\mathrm{CD} 1$ ), more recent studies have also clearly identified an association between bona fide NK cell deficits in the peripheral blood with many autoimmune disorders [55] including autoimmune thyroid disease $[56,57]$ and psoriasis $[58]$ as well as a number of pediatric rheumatologic diseases including juvenile dermatomyositis [59] and systemic-onset juvenile idiopathic arthritis (JIA) [60].

The significance of these correlative studies to the pathogenesis of autoimmune diseases is not clear. Although these reports raise the possibility that autoimmunity may be associated with NK cell numeric or functional deficiencies, such conclusions must be tempered by the fact that these observations have been based primarily on studies of peripheral blood samples that cannot distinguish between true deficits and sequestration of NK cells in target tissues. Furthermore, the clinical courses of rare patients with complete NK cell deficiencies are dominated by overwhelming viral infections rather than autoimmune syndromes [61-63].

In contrast to reports based solely on decreased numbers of NK cells in the peripheral blood, several studies have demonstrated accumulation of NK cells in affected tissues of autoimmune patients. For example, infiltrating NK cells have been found to accrue in the pancreatic islet of T1DM patients [64], the hair follicle of patients with alopecia areata [65], and the muscle of children with juvenile dermatomyositis [66,67]. Interestingly, CD56 ${ }^{\text {bright }} \mathrm{NK}$ cells, in particular, accumulate in the skin lesions of psoriatic patients [68] and the synovium of RA patients $[69,70]$. These observations support the hypothesis that decreased NK cells in the peripheral blood of patients with autoimmune disorders may reflect the trafficking of NK cells to affected tissues.

Also unclear is whether the reported alterations in NK cell localization and functional responses are primary defects involved in disease pathogenesis or occur secondary to the disease and its treatments. However, NK cell defects have been identified in treatment-naïve patients before overt progression to disease or at the time of diagnosis, demonstrating that the defects are not solely treatment related or the result of chronic inflammation from long-standing disease [59,71]. Furthermore, studies in T1DM have demonstrated modestly decreased NK cell numbers in the peripheral blood of patients with recentonset T1DM but not in patients with long-standing T1DM [72]. Interestingly, NK cells were identified around the islet cells of a subset of patients with recentonset T1DM [64] but not in postmortem pancreatic samples from T1DM patients with long-standing disease [73]. Murine models of T1DM have also demonstrated localization of NK cells near islets as well as a temporal correlation in NK cell infiltrates during the development of diabetes, with a greater influx of NK cells during the prediabetic stage compared with late diabetes [74-76]. In other disorders such as dermatomyositis-polymyositis and MS, deficits observed in NK cell cytotoxicity in patients with active disease were not seen in patients with quiescent disease $[77,78]$. Together, these findings suggest that NK cells may contribute to the initiation of the autoimmune process but may be less important in established disease; however, further study is needed to confirm this conclusion.

Chronic NK cell lymphocytosis, a disorder characterized by a persistent elevation of NK cells in the peripheral blood, provides some novel insights into the potential contributions of NK cells to autoimmune disorders. Studies in both humans and mice suggest that chronic NK cell lymphocytosis results from an aberrant expansion of an immature NK cell population with functional deficits [79-81]. In addition to cytopenia, chronic NK cell lymphocytosis is associated with autoimmune syndromes, including vasculitis, arthritis, and peripheral neuropathy [82-84]. This disorder provides evidence that the dysregulation of NK cell homeostasis in the context of decreased NK cell cytotoxicity may contribute to the onset of autoimmunity.

\section{Killer immunoglobulin-like receptor/HLA associations}

Genetic association studies in a variety of autoimmune disorders provide strong evidence that NK cells contribute to the pathogenesis of human autoimmune disorders (reviewed in $[85,86]$ ). KIRs are polymorphic, germlineencoded receptors expressed on NK cells (and a subset of $\mathrm{T}$ cells) that recognize HLA. The KIR locus is complex with more than 20 different haplotypes encoding various numbers of inhibitory and activating KIRs, which in the context of the individual's HLA genotype influence NK cell licensing and activation $[25,30]$. 
KIR/HLA genotype combinations that favor NK cell activation are often beneficial in protecting against infections [86]. For example, in individuals infected with HIV, the combination of KIR3DS1 and HLA-B Bw4-801 is associated with slower progression to AIDS, decreased viral loads, and fewer opportunistic infections $[87,88]$. However, these same activating KIR/HLA genotype combinations predispose individuals to autoimmune disorders, including Behçet's disease, T1DM, SLE, MS, psoriasis/psoriatic arthritis, ankylosing spondylitis, and RA [89-96]. For example, scleroderma is associated with the activating KIR2DS2 in the absence of its corresponding inhibitory KIR2DL2 [97]. Similarly, psoriatic arthritis is linked to the expression of KIR2DS1 and/or KIR2DS2 in the absence of the ligands for the corresponding homologous inhibitory receptors [93]. The presence of activating KIRs or KIR/HLA genotypes in the context of decreased NK cell inhibition (for example, absence of corresponding inhibitory KIRs or the HLA ligands for the inhibitory KIRs) therefore results in a lower activation threshold for NK cells (or potentially $\mathrm{T}$ cells) and predisposes to autoimmunity. The association of activating KIRs and KIR/HLA genotypes with autoimmune disorders provides compelling evidence implicating NK cells in human autoimmunity.

\section{Multiple sclerosis}

MS is an inflammatory disorder that affects the central nervous system (CNS). It may follow a relapsingremitting (85 to 90\%) or primary progressive course. Autoreactive CD4 $\mathrm{T}$ cells targeting myelin components are critical mediators of the inflammatory process, particularly in the early stages of relapsing-remitting MS. However, studies in both humans and mice have implicated NK cells in the pathogenesis of MS $[98,99]$.

Human NK cells are postulated to play an immunoregulatory role in MS by killing activated T cells [100]; however, they can also directly lyse oligodendrocytes, astrocytes, and microglia through recognition of NKG2D ligands [101,102], raising the possibility that NK cells may exert either a beneficial or deleterious influence on the development of MS. Indeed, studies in experimental autoimmune encephalomyelitis, a rodent model of MS, underscore the potential of NK cells to either suppress or augment CD4 T-cell-mediated CNS inflammation. The majority of experimental autoimmune encephalomyelitis studies have demonstrated that depletion of NK cells [103-105] or blockade of NK cell homing to the CNS via deletion of the chemokine receptor CX3CR1 [106] resulted in severe, relapsing experimental autoimmune encephalomyelitis and increased mortality. However, other investigators have reported that NK cell depletion resulted in less severe disease [107] and that IL-18- and IL21-mediated exacerbations of experimental autoimmune encephalomyelitis were NK cell dependent [108,109]. These results suggest that the influence of NK cells on the pathogenesis of MS is probably modulated by the inflammatory milieu, the phase of the disease, and other factors.

A temporal correlation between NK cell numbers or cytotoxicity and periods of disease progression or remission in MS supports the hypothesis that NK cells may play an immunoregulatory role in disease pathology $[77,110]$. For example, a study of relapsing-remitting MS patients demonstrated that depressed NK cell cytotoxicity preceded the appearance of contrast-enhancing CNS lesions on magnetic resonance imaging and the onset of clinical symptoms [77]. In addition, NK cells from MS patients in remission express high levels of CD95 (Fas, a TNF receptor superfamily member involved in inducing apoptosis) and appear to suppress autoimmune T cells [111]. Indeed, CD95 high NK cells from MS patients were able to directly inhibit T-cell IFNY production following ex vivo stimulation with myelinbasic protein [112]. Interestingly, NK cells in the blood of MS patients lose the CD $95^{\text {high }}$ phenotype during disease relapse and regain it after recovery [111].

Paired blood and cerebrospinal fluid samples from MS patients demonstrated a substantial enrichment of CD56 ${ }^{\text {bright }}$ NK cells in the cerebrospinal fluid [113]. Treatment of MS patients with daclizumab (a humanized anti IL-2R $\alpha$ antibody) caused a significant expansion of CD56 ${ }^{\text {bright }} \mathrm{NK}$ cells in the periphery as well as a decrease in circulating CD4 $\mathrm{T}$ cells $[114,115]$. The daclizumabinduced increase in CD56 ${ }^{\text {bright }}$ NK cells correlated with decreased magnetic resonance imaging contrastenhancing CNS lesions in MS patients [114,115]. Furthermore, CD56 ${ }^{\text {bright }}$ NK cells from MS patients treated with daclizumab were able to kill autologous CD4 $\mathrm{T}$ cells ex vivo without IL-2 priming [114]. Taken together, the deficits in peripheral NK cell numbers in MS patients [110], the temporal correlation between NK cell cytotoxicity and disease flares, the accumulation of CD56 ${ }^{\text {bright }} \mathrm{NK}$ cells in the cerebrospinal fluid, and the correlation of the expansion of CD56 $6^{\text {bright }}$ NK cells with decreased flares during effective immunotherapy support the hypothesis that NK cells play an immunoregulatory role in MS. However, definitive evidence of NK cell participation in the pathogenesis of MS will require further study.

\section{Rheumatoid arthritis}

RA is a chronic autoimmune disease characterized by inflammation of joints and surrounding tissues that leads to cartilage destruction and bone erosions. It is associated with elevated levels of proinflammatory cytokines (for example, TNFo, IL-1, IL-6, and IL-23) and inflammatory cell infiltrates (including $\mathrm{T}$ cells, $\mathrm{B}$ cells, and macrophages) 
in the affected joints. Recent studies have implicated human NK cells in the pathogenesis of RA (reviewed in $[116,117])$.

NK cells comprised a significant fraction of the lymphocytes (8 to 25\%) in the synovial fluid of RA patients and could be detected in the joint early during the disease course [118]. Similar to the observations in the cerebrospinal fluid of MS patients, the majority of the NK cells in the synovial fluid of RA patients were CD56 $6^{\text {bright }}(\sim 60 \%$ of NK cells) with elevated expression of CD94/NKG2A and decreased expression of KIRs and CD16 [69,70]. The CD56 bright $^{\text {subpopulation of NK cells }}$ was also found in the blood of RA patients (and normal controls) but at much lower frequencies $(\sim 10 \%$ of NK cells). The NK cells within the synovium also showed upregulated expression of several chemokine receptors and adhesion molecules that may participate in preferential recruitment into the synovium [69]. The synovial CD56 ${ }^{\text {bright }}$ NK cells expressed higher levels of activation markers (CD69 and NKp44) and produced more TNF $\alpha$ as well as IFNY than $\mathrm{CD} 56^{\text {bright }} \mathrm{NK}$ cells from the peripheral blood of the same patients [119]. Synovial NK cells could induce monocytes to differentiate into DCs [120] and have also been shown to produce IL-22, a cytokine that induces proliferation of synovial fibroblasts [121]. Aberrant expression of MHC class I polypeptiderelated sequence A in the inflamed synovium [122] may augment CD56 bright $\mathrm{NK}$ cell activation, resulting in dysregulated production of proinflammatory cytokines rather than in immunoregulation. Taken together, these findings suggest that the enrichment of CD56 $6^{\text {bright }} \mathrm{NK}$ cells may contribute to the initiation and/or perpetuation of dysregulated production of proinflammatory cytokines in the synovium of RA patients $[69,70]$.

In contrast to the accumulation of activated CD $56^{\text {bright }}$ NK cells in the synovium, patients with RA have decreased circulating NK cells in their peripheral blood [55]. In addition to the numeric deficit, peripheral blood NK cells in RA patients have decreased cytotoxicity on a per-cell basis [123]. Low numbers of peripheral blood NK cells and decreased cytotoxicity have also been identified in patients with JIA, with the most prominent deficits occurring in systemic JIA patients [60,124-126]. Furthermore, a significant subset of systemic JIA patients had almost a complete absence of circulating CD56 ${ }^{\text {bright }}$ NK cells $[126,127]$. The depressed NK cell cytotoxicity in systemic JIA patients was not solely accounted for by the reduced numeric frequency of NK cells $[125,126]$ and was associated with low levels of perforin $[124,126]$. The impaired NK cell functional responses in systemic JIA patients have also been linked to defective IL-18R $\beta$ phosphorylation [127] and heterozygous missense mutations in components of the cytolytic pathway [128-130].
These observations in conjunction with the genetic associations between inflammatory arthritis and KIR haplotypes support the hypothesis that dysregulation of cytokine production by CD56 $6^{\text {bight }}$ NK cells in the synovium and/or decreased cytotoxicity by peripheral CD56 ${ }^{\text {dim }}$ NK cells may contribute to pathogenesis of RA. This hypothesis is further corroborated by findings in several distinct murine models of inflammatory arthritis (for example, collagen-induced arthritis and Staphylococcus aureus-associated arthritis), which have demonstrated that NK cell depletion results in earlier onset of arthritis, more severe disease, and increased autoantibody and IL-17 production [131,132]. Interestingly, reduced peripheral NK cell numbers and decreased cytotoxicity were also observed in the collagen-induced arthritis model [131]. NK cell-generated IFN $\gamma$ was shown to suppress the generation of Th17 cells (collageninduced arthritis model [131]) as well as neurophil recruitment to the affected joints $(\mathrm{K} / \mathrm{BxN}$ model, an autoantibody model of arthritis [133]). Furthermore, activation of NK cells by blockade of the inhibitory CD94/NKG2A receptor inhibited the development of arthritis via perforin-dependent cytolysis of Th17 and Tfollicular helper cells in the collagen-induced arthritis model [134]. However, conclusions about the role of NK cells in regulating autoimmune arthritis in murine models must be tempered by a conflicting report that depletion of NK cells reduced the severity of arthritis and prevented bone erosions in the collagen-induced arthritis model [135].

\section{Systemic lupus erythematosus}

SLE is an immune complex-mediated disorder resulting in widespread organ dysfunction primarily in reproductive-age females. SLE is characterized by polyclonal B-cell activation and the production of a wide array of autoantibodies against nuclear proteins and DNA. Insights from murine models have implicated NK cells in the development of autoantibodies and other features of SLE [136]. For example, the development of an SLE-like disorder in C57BL/6 lpr mice (which have a defect in the Fas gene) is temporally related to an age-dependent loss of NK and NKT cells. Furthermore, NK cell depletion in these mice enhanced development of autoantibodysecreting B cells while the adoptive transfer of NK cells delayed the onset of autoantibody production [137]. Human SLE studies have also provided intriguing observations linking NK cells with the development of SLE.

Numeric deficits in peripheral NK cells have been reported in multiple cohorts of SLE patients [55,71, 138-141] and correlate with clinical manifestations of SLE, including lupus nephritis and thrombocytopenia [55], and overall disease activity $[142,143]$. Interestingly, 
an increased proportion of CD56 bright $^{\text {NK cells has been }}$ observed in SLE patients regardless of disease activity [144]. In addition to numeric deficits in peripheral NK cells, depressed cytotoxicity responses on a per-cell basis have been consistently documented in SLE patients $[55,71,140,145]$ as well as in a subset of first-degree relatives [145]. An early study in pediatric SLE patients was particularly informative since it demonstrated low numbers of peripheral NK cells and defective cytolysis (on a single cell level) at diagnosis or even prior to overt progression to SLE in a subset of patients [71]. However, the majority of the human data on NK cells in SLE are correlative, and the role of NK cells in the development of SLE in humans remains less well established than NK cell contributions in RA and MS.

\section{Conclusion}

By virtue of their ability to rapidly kill abnormal cells and produce cytokines and chemokines, NK cells influence and shape adaptive immune responses and are positioned to play a role in regulating autoimmune responses. Genetic association studies implicate NK cells in the pathogenesis of human autoimmune disorders. Studies in MS, RA, and SLE, which are summarized in this review, provide tantalizing but incomplete evidence for contributions of specific subsets of NK cells (in both the periphery and affected tissues) to the onset or progression of autoimmunity. The associations found in humans and the empirical evidence from murine models demonstrate that further research into the immunomodulatory role of NK cells in autoimmunity is warranted and is likely to provide novel insights into the pathogenesis of autoimmune disorders. Furthermore, the expansion of CD56 ${ }^{\text {bright }}$ NK cells during effective immunotherapy and the correlation with decreased MS flares suggests that a better understanding of the role of NK cells in development of autoimmunity may lead to new therapeutic targets in these diseases.

\section{Abbreviations}

CNS, central nervous system; DC, dendritic cell; HLA, human leukocyte antigen; IFN, interferon; IL, interleukin; JIA, juvenile idiopathic arthritis; KIR, killer immunoglobulin-like receptor; MHC, major histocompatibility complex; MS, multiple sclerosis; NK, natural killer; RA, rheumatoid arthritis; SLE, systemic lupus erythematosus; STXBP2, syntaxin binding protein 2; T1DM, type I diabetes mellitus; Th, T-helper; TNF, tumor necrosis factor.

\section{Competing interests}

The authors declare that they have no competing interests.

\section{Acknowledgements}

This work was supported by the Howard Hughes Medical Institute and National Institutes of Health R01-Al078994 (ARF), R01-Al073552 (ARF), R01Al51345 (WMY), R01-Al33903 (WMY), and R37-A1034385 (WMY) grants.

\section{Author details}

'Division of Pediatric Rheumatology, Department of Pediatrics, Washington University, Box 8208, 660 South Euclid Avenue, St Louis, MO 63110, USA.

${ }^{2}$ Howard Hughes Medical Institute, Division of Rheumatology, Department of Medicine, Washington University School of Medicine, St Louis, MO 63110, USA.
Published: 11 July 2013

\section{References}

1. Progress in Autoimmune Diseases Research

[http://www.niaid.nih.gov/topics/autoimmune/documents/adccfinal.pdf]

2. The Cost Burden of Autoimmune Disease: The Latest Front in the War on Healthcare Spending [http://www.aarda.org/pdf/cbad.pdf]

3. Yokoyama WM, Kim S, French AR: The dynamic life of natural killer cells. Annu Rev Immuno/ 2004, 22:405-429.

4. Walzer T, Jaeger S, Chaix J, Vivier E: Natural killer cells: from CD3(-)NKp46(+) to post-genomics meta-analyses. Curr Opin Immunol 2007, 19:365-372.

5. Shi F-D, Ljunggren HG, La Cava A, Van Kaer L: Organ-specific features of natural killer cells. Nat Rev Immuno/ 2011, 11:658-671.

6. Hanna J, Goldman-Wohl D, Hamani Y, Avraham I, Greenfield C, NatansonYaron S, Prus D, Cohen-Daniel L, Arnon TI, Manaster I, Gazit R, Yutkin V, Benharroch D, Porgador A, Keshet E, Yagel S, Mandelboim O: Decidual NK cells regulate key developmental processes at the human fetal-maternal interface. Nat Med 2006, 12:1065-1074.

7. King A, Burrows T, Verma S, Hiby S, Loke YW: Human uterine lymphocytes. Hum Reprod Update 1998, 4:480-485.

8. Cooper MA, Fehniger TA, Turner SC, Chen KS, Ghaheri BA, Ghayur T, Carson WE, Caligiuri MA: Human natural killer cells: a unique innate immunoregulatory role for the CD56(bright) subset. Blood 2001, 97:3146-3151.

9. Caligiuri MA: Human natural killer cells. Blood 2008, 112:461-469

10. Fehniger TA, Cooper MA, Nuovo GJ, Cella M, Facchetti F, Colonna M, Caligiuri MA: CD56 $6^{\text {bright }}$ natural killer cells are present in human lymph nodes and are activated by T cell-derived IL-2: a potential new link between adaptive and innate immunity. Blood 2003, 101:3052-3057.

11. Gumperz JE, Litwin V, Phillips JH, Lanier LL, Parham P: The Bw4 public epitope of HLA-B molecules confers reactivity with natural killer cell clones that express NKB1, a putative HLA receptor. J Exp Med 1995, 181:1133-1144.

12. Cella M, Longo A, Ferrara GB, Strominger $J$, Colonna M: NK3-specific natural killer cells are selectively inhibited by Bw4-positive HLA alleles with isoleucine 80. J Exp Med 1994, 180:1235-1242.

13. Braud VM, Allen DSJ, O'Callaghan CA, Söderström K, D'Andrea A, Ogg GS, Lazetic S, Young NT, Bell Jl, Phillips JH, Lanier LL, McMichael AJ: HLA-E binds to natural-killer-cell receptors CD94/NKG2A, B and C. Nature 1998, 391:795-799.

14. Borrego F, Ulbrecht M, Weiss EH, Coligan JE, Brooks AG: Recognition of human histocompatibility leukocyte antigen (HLA)-E complexed with HLA class I signal sequence-derived peptides by CD94/NKG2 confers protection from natural killer cell-mediated lysis. J Exp Med 1998, 187:813-818.

15. Lee N, Llano M, Carretero M, Ishitani A, Navarro F, López-Botet M, Geraghty DE: HLA-E is a major ligand for the NK inhibitory receptor CD94/NKG2A Proc Natl Acad SciU SA 1998, 95:5199-5204.

16. Bauer S, Groh V, Wu J, Steinle A, Phillips JH, Lanier LL, Spies T: Activation of NK cells and T cells by NKG2D, a receptor for stress-inducible MICA. Science 1999, 285:727-729.

17. Mandelboim O, Lieberman N, Lev M, Paul L, Arnon TI, Bushkin Y, Davis DM, Strominger JL, Yewdell JW, Porgador A: Recognition of haemagglutinins on virus-infected cells by NKp46 activates lysis by human NK cells. Nature 2001, 409:1055-1060.

18. Ljunggren $H G$, Karre K: In search of the 'missing self': MHC molecules and NK cell recognition. Immunol Today 1990, 11:237-244.

19. Kärre K, Ljunggren HG, Piontek G, Kiessling R: Selective rejection of $\mathrm{H}-2$ deficient lymphoma variants suggests alternative immune defence strategy. Nature 1986, 319:675-678.

20. Gasser S, Orsulic S, Brown EJ, Raulet DH: The DNA damage pathway regulates innate immune system ligands of the NKG2D receptor. Nature 2005, 436:1186-1190.

21. Stern-Ginossar N, Gur C, Biton M, Horwitz E, Elboim M, Stanietsky N, Mandelboim M, Mandelboim O: Human microRNAs regulate stress-induced immune responses mediated by the receptor NKG2D. Nat Immuno/ 2008 , 9:1065-1073.

22. Jonsson AH, Yokoyama WM: Natural killer cell tolerance licensing and other mechanisms. Adv Immunol 2009 101:27-79.

23. Elliott JM, Yokoyama WM: Unifying concepts of MHC-dependent natural killer cell education. Trends Immuno/ 2011, 32:364-372. 
24. Zimmer J, Donato L, Hanau D, Cazenave JP, Tongio MM, Moretta A, de la Salle $\mathrm{H}$ : Activity and phenotype of natural killer cells in peptide transporter (TAP)-deficient patients (type I bare lymphocyte syndrome). J Exp Med 1998, 187:117-122.

25. Anfossi N, Andre P, Guia S, Falk CS, Roetynck S, Stewart CA, Breso V, Frassati C, Reviron D, Middleton D, Romagné F, Ugolini S, Vivier E: Human NK cell education by inhibitory receptors for MHC class I. Immunity 2006, 25:331-342

26. Fernandez NC, Treiner E, Vance RE, Jamieson AM, Lemieux S, Raulet DH: A subset of natural killer cells achieves self-tolerance without expressing inhibitory receptors specific for self-MHC molecules. Blood 2005, 105:4416-4423.

27. Kim S, Poursine-Laurent J, Truscott SM, Lybarger L, Song YJ, Yang L, French AR, Sunwoo JB, Lemieux S, Hansen TH, Yokoyama WM: Licensing of natural killer cells by host major histocompatibility complex class I molecules. Nature 2005, 436:709-713.

28. Yokoyama WM, Kim S: Licensing of natural killer cells by self-major histocompatibility complex class I. Immunol Rev 2006, 214:143-154.

29. Yokoyama WM, Kim S: How do natural killer cells find self to achieve tolerance? Immunity 2006, 24:249-257.

30. Kim S, Sunwoo JB, Yang L, Choi T, Song YJ, French AR, Vlahiotis A, Piccirillo JF, Cella M, Colonna M, Mohanakumar T,Hsu KC, Dupont B, Yokoyama WM: HLA alleles determine differences in human natural killer cell responsiveness and potency. Proc Natl Acad Sci U S A 2008, 105:3053-3058.

31. Mailliard RB, Son Y-I, Redlinger R, Coates PT, Giermasz A, Morel PA, Storkus WJ, Kalinski P: Dendritic cells mediate NK cell help for Th1 and CTL responses: two-signal requirement for the induction of NK cell helper function. $\mathrm{J}$ Immuno/ 2003, 171:2366-2373.

32. Piccioli D, Sbrana S, Melandri E, Valiante NM: Contact-dependent stimulation and inhibition of dendritic cells by natural killer cells. J Exp Med 2002, 195:335-341.

33. Mocikat R, Braumuller H, Gumy A, Egeter O, Ziegler $H$, Reusch U, Bubeck A, Louis J, Mailhammer R, Riethmuller G, Koszinowski U, Röcken M: Natural killer cells activated by MHC class I(low) targets prime dendritic cells to induce protective CD8 T cell responses. Immunity 2003, 19:561-569.

34. Ferlazzo G, Tsang ML, Moretta L, Melioli G, Steinman RM, Münz C: Human dendritic cells activate resting natural killer (NK) cells and are recognized via the NKp30 receptor by activated NK cells. J Exp Med 2002, 195:343-351.

35. Pende D, Castriconi R, Romagnani P, Spaggiari GM, Marcenaro S, Dondero A, Lazzeri E, Lasagni L, Martini S, Rivera P, Capobianco A, Moretta L, Moretta A, Bottino C: Expression of the DNAM-1 ligands, Nectin-2 (CD112) and poliovirus receptor (CD155), on dendritic cells: relevance for natural killerdendritic cell interaction. Blood 2006, 107:2030-2036.

36. Nedvetzki S, Sowinski S, Eagle RA, Harris J, Vély F, Pende D, Trowsdale J, Vivier E, Gordon S, Davis DM: Reciprocal regulation of human natural killer cells and macrophages associated with distinct immune synapses. Blood 2007 109:3776-3785.

37. Cerboni C, Zingoni A, Cippitelli M, Piccoli M, Frati L, Santoni A: Antigenactivated human T lymphocytes express cell-surface NKG2D ligands via an ATM/ATR-dependent mechanism and become susceptible to autologous NK-cell lysis. Blood 2007, 110:606-615.

38. Molinero LL, Domaica Cl, Fuertes MB, Girart MV, Rossi LE, Zwirner NW: Intracellular expression of MICA in activated CD4 T lymphocytes and protection from NK cell-mediated MICA-dependent cytotoxicity. Hum Immunol 2006, 67:170-182.

39. Zingoni A, Palmieri G, Morrone S, Carretero M, Lopez-Botel M, Piccoli M, Frat $L$, Santoni A: CD69-triggered ERK activation and functions are negatively regulated by CD94/NKG2-A inhibitory receptor. Eur J Immuno/ 2000, 30:644-651.

40. De Maria A, Fogli M, Mazza S, Basso M, Picciotto A, Costa P, Congia S, Mingari $M C$, Moretta $L$ : Increased natural cytotoxicity receptor expression and relevant IL-10 production in NK cells from chronically infected viremic HCV patients. Eur J Immunol 2007, 37:445-455.

41. Mehrotra PT, Donnelly RP, Wong S, Kanegane H, Geremew A, Mostowski HS, Furuke K, Siegel JP, Bloom ET: Production of IL-10 by human natural killer cells stimulated with IL-2 and/or IL-12. J Immuno/ 1998, 160:2637-2644.

42. Deniz G, Erten G, Kücüksezer UC, Kocacik D, Karagiannidis C, Aktas E, Akdis CA, Akdis M: Regulatory NK cells suppress antigen-specific T cell responses. J Immunol 2008, 180:850-857.

43. Martin-Fontecha A, Thomsen LL, Brett S, Gerard C, Lipp M, Lanzavecchia A, Sallusto F: Induced recruitment of NK cells to lymph nodes provides
IFN-gamma for $\mathrm{T}(\mathrm{H}) 1$ priming. Nat Immunol 2004, 5:1260-1265.

44. Morandi B, Bougras G, Muller WA, Ferlazzo G, Munz C: NK cells of human secondary lymphoid tissues enhance $T$ cell polarization via IFN-gamma secretion. Eur J Immuno/ 2006, 36:2394-2400.

45. Grossman WJ, Verbsky JW, Barchet W, Colonna M, Atkinson JP, Ley TJ: Human T regulatory cells can use the perforin pathway to cause autologous target cell death. Immunity 2004, 21:589-601.

46. Risma K, Jordan MB: Hemophagocytic lymphohistiocytosis: updates and evolving concepts. Curr Opin Pediatr 2012, 24:9-15.

47. Côte M, Ménager MM, Burgess A, Mahlaoui N, Picard C, Schaffner C, Al-Manjomi F, Al-Harbi M, Alangari A, Le Deist F, Gennery AR, Prince N, Cariou A, Nitschke P, Blank U, El-Ghazali G, Ménasché G, Latour S, Fischer A, de Saint Basile G: Munc18-2 deficiency causes familial hemophagocytic lymphohistiocytosis type 5 and impairs cytotoxic granule exocytosis in patient NK cells. J Clin Invest 2009, 119:3765-3773.

48. Schleinitz N, Vély F, Harlé J-R, Vivier E: Natural killer cells in human autoimmune diseases. Immunology 2010, 131:451-458.

49. Grunebaum E, Malatzky-Goshen E, Shoenfeld Y: Natural killer cells and autoimmunity. Immunol Res 1989, 8:292-304

50. Baxter AG, Smyth MJ: The role of NK cells in autoimmune disease. Autoimmunity 2002, 35:1-14.

51. Flodstrom M, Shi FD, Sarvetnick N, Ljunggren HG: The natural killer cell friend or foe in autoimmune disease? Scand J Immuno/ 2002, 55:432-441.

52. French AR, Yokoyama WM: Natural killer cells and autoimmunity. Arthritis Res Ther 2004, 6:8-14

53. Flodström-Tullberg M, Bryceson $Y T$, Shi F-D, Höglund $P$, Ljunggren $H-G$ : Natural killer cells in human autoimmunity. Curr Opin Immunol 2009, 21:634-640.

54. Tian Z, Gershwin ME, Zhang C: Regulatory NK cells in autoimmune disease. J Autoimmun 2012, 39:206-215.

55. Park YW, Kee SJ, Cho YN, Lee EH, Lee HY, Kim EM, Shin MH, Park JJ, Kim TJ, Lee SS, Yoo DH, Kang HS: Impaired differentiation and cytotoxicity of natural killer cells in systemic lupus erythematosus. Arthritis Rheum 2009, 60:1753-1763.

56. Bossowski A, Urban M, Stasiak-Barmuta A: Analysis of circulating T gamma/ delta lymphocytes and CD16/56 cell populations in children and adolescents with Graves' disease. Pediatr Res 2003, 54:425-429

57. Ciampolillo A, Guastamacchia E, Amati L, Magrone T, Munno I, Jirillo E, Triggiani V, Fallacara R, Tafaro E: Modifications of the immune responsiveness in patients with autoimmune thyroiditis: evidence for a systemic immune alteration. Curr Pharm Des 2003, 9:1946-1950.

58. Cameron AL, Kirby B, Griffiths CEM: Circulating natural killer cells in psoriasis. Br J Dermatol 2003, 149:160-164.

59. O'Gorman MR, Smith R, Garrison A, Shamiyeh E, Pachman L: Lymphocyte subsets in peripheral blood from newly diagnosed, untreated patients with juvenile dermatomyositis (JDM) are associated with disease activity scores (DAS). Arthritis Rheum 2002, 46:S490.

60. Wouters $\mathrm{CH}$, Ceuppens JL, Stevens EA: Different circulating lymphocyte profiles in patients with different subtypes of juvenile idiopathic arthritis. Clin Exp Rheumatol 2002, 20:239-248

61. Biron CA, Byron KS, Sullivan JL: Severe herpesvirus infections in an adolescent without natural killer cells. N Engl J Med 1989, 320:1731-1735.

62. Jawahar S, Moody C, Chan M, Finberg R, Geha R, Chatila T: Natural Killer (NK) cell deficiency associated with an epitope-deficient Fc receptor type IIIA (CD16-II). Clin Exp Immunol 1996, 103:408-413.

63. Orange JS: Human natural killer cell deficiencies and susceptibility to infection. Microbes Infect 2002, 4:1545-1558.

64. Dotta F, Censini S, van Halteren AGS, Marselli L, Masini M, Dionisi S, Mosca F, Boggi U, Muda AO, Del Prato S, Elliott JF,Covacci A, Rappuoli R, Roep BO, Marchetti P: Coxsackie B4 virus infection of beta cells and natural killer cell insulitis in recent-onset type 1 diabetic patients. Proc Nat/ Acad Sci U S A 2007, 104:5115-5120

65. Ito T, Ito N, Saatoff M, Hashizume H, Fukamizu H, Nickoloff BJ, Takigawa M, Paus R: Maintenance of hair follicle immune privilege is linked to prevention of NK cell attack. J Invest Dermato/ 2008, 128:1196-1206.

66. Li CK, Varsani H, Holton JL, Gao B, Woo P, Wedderburn LR: Juvenile Dermatomyositis Research Group (UK and Ireland): MHC class I overexpression on muscles in early juvenile dermatomyositis. J Rheumatol 2004, 31:605-609.

67. Pachman L, O'Gorman MR, Lawton T, Liotta M, Pope RM, Greene M, Wu TT: Studies of muscle biopsies from DQA $501^{+}$untreated children with 
juvenile dermatomyositis very early in their disease course: evidence of a TCRb8 motif and increase CD56 ${ }^{+}$NK cells. Arthritis Rheum 1998, 41(Suppl 9):203.

68. Ottaviani C, Nasorri F, Bedini C, de Pità O, Girolomoni G, Cavani A: CD56brightCD16(-) NK cells accumulate in psoriatic skin in response to CXCL10 and CCL5 and exacerbate skin inflammation. Eur J Immuno/ 2006 36:118-128.

69. Dalbeth N, Callan MFC: A subset of natural killer cells is greatly expanded within inflamed joints. Arthritis Rheum 2002, 46:1763-1772.

70. Pridgeon C, Lennon GP, Pazmany L, Thompson RN, Christmas SE, Moots RJ: Natural killer cells in the synovial fluid of rheumatoid arthritis patients exhibit a CD56 ${ }^{\text {bright }}, C D 94^{\text {bright }}, C D 158^{\text {negative }}$ phenotype. Rheumatology (Oxford) 2003, 42:870-878.

71. Yabuhara A, Yang FC, Nakazawa T, Iwasaki Y, Mori T, Koike K, Kawai H, Komiyama A: A killing defect of natural killer cells as an underlying immunologic abnormality in childhood systemic lupus erythematosus. J Rheumatol 1996, 23:171-177.

72. Rodacki M, Svoren B, Butty V, Besse W, Laffel L, Benoist C, Mathis D: Altered natural killer cells in type 1 diabetic patients. Diabetes 2007, 56:177-185

73. Willcox A, Richardson SJ, Bone AJ, Foulis AK, Morgan NG: Analysis of islet inflammation in human type 1 diabetes. Clin Exp Immunol 2009, 155:173-181.

74. Gur C, Porgador A, Elboim M, Gazit R, Mizrahi S, Stern-Ginossar N, Achdout H, Ghadially H, Dor Y, Nir T, Doviner V, Hershkovitz O, Mendelson M, Naparstek Y, Mandelboim O: The activating receptor NKp46 is essential for the development of type 1 diabetes. Nat Immunol 2010, 11:121-128.

75. Poirot L, Benoist C, Mathis D: Natural killer cells distinguish innocuous and destructive forms of pancreatic islet autoimmunity. Proc Natl Acad Sci U S A 2004, 101:8102-8107.

76. Brauner H, Elemans M, Lemos S, Broberger C, Holmberg D, FlodstromTullberg M, Karre K, Hoglund P: Distinct phenotype and function of NK cells in the pancreas of nonobese diabetic mice. J Immuno/ 2010, 184:2272-2280.

77. Kastrukoff LF, Morgan NG, Zecchini D, White R, Petkau AJ, Satoh J, Paty DW: A role for natural killer cells in the immunopathogenesis of multiple sclerosis. J Neuroimmunol 1998, 86:123-133.

78. Gonzalez-Amaro R, Alcocer-Varela J, Alarcón-Segovia D: Natural killer cell activity in dermatomyositis-polymyositis. J Rheumatol 1987, 14:307-310.

79. Lima M, Almeida J, Montero AG, Teixeira Mdos A, Queiros ML, Santos AH, Balanzategui A, Estevinho A, Alguero Mdel C, Barcena P, Fonseca S, Amorim ML, Cabeda JM, Pinho L, Gonzalez M, San Miguel J, Justiça B, Orfão A: Clinicobiological, immunophenotypic, and molecular characteristics of monoclonal $\mathrm{CD} 56^{-/+ \text {dim }}$ chronic natural killer cell large granular lymphocytosis. Am J Pathol 2004, 165:1117-1127.

80. Orange JS, Chehimi J, Ghavimi D, Campbell D, Sullivan KE: Decreased natural killer (NK) cell function in chronic NK cell lymphocytosis associated with decreased surface expression of CD11b. Clin Immunol 2001, 99:53-64.

81. French AR, Kim S, Fehniger TA, Pratt JR, Yang L, Song YJ, Caligiuri MA, Yokoyama WM: Chronic lymphocytosis of functionally immature natural killer cells. J Allergy Clin Immuno/ 2007, 120:924-931.

82. Lamy T, Loughran TP Jr: Clinical features of large granular lymphocyte leukemia. Semin Hematol 2003, 40:185-195.

83. Tefferi A, Li CY, Witzig TE, Dhodapkar MV, Okuno SH, Phyliky RL: Chronic natural killer cell lymphocytosis: a descriptive clinical study. Blood 1994 84:2721-2725

84. Rabbani GR, Phyliky RL, Tefferi A: A long-term study of patients with chronic natural killer cell lymphocytosis. Br J Haematol 1999, 106:960-966.

85. Bashirova AA, Martin MP, McVicar DW, Carrington M: The killer immunoglobulin-like receptor gene cluster: tuning the genome for defense. Annu Rev Genomics Hum Genet 2006, 7:277-300

86. Kulkarni S, Martin MP, Carrington M: The Yin and Yang of HLA and KIR in human disease. Semin Immunol 2008, 20:343-352.

87. Martin MP, Gao X, Lee J-H, Nelson GW, Detels R, Goedert JJ, Buchbinder S, Hoots K, Vlahov D, Trowsdale J, Wilson M,O'Brien SJ, Carrington M: Epistatic interaction between KIR3DS1 and HLA-B delays the progression to AIDS Nat Genet 2002, 31:429-434

88. Alter G, Martin MP, Teigen N, Carr WH, Suscovich TJ, Schneidewind A, Streeck H, Waring M, Meier A, Brander C, Lifson JD, Allen TM, Carrington M, Altfeld M Differential natural killer cell-mediated inhibition of HIV-1 replication based on distinct KIR/HLA subtypes. J Exp Med 2007, 204:3027-3036.

89. Yen JH, Moore BE, Nakajima T, Scholl D, Schaid DJ, Weyand CM, Goronzy JJ: Major histocompatibility complex class i-recognizing receptors are disease risk genes in rheumatoid arthritis. J Exp Med 2001, 193:1159-1 168.

90. Martin MP, Nelson G, Lee J-H, Pellett F, Gao X, Wade J, Wilson MJ, Trowsdale J, Gladman D, Carrington M: Cutting edge: susceptibility to psoriatic arthritis: influence of activating killer lg-like receptor genes in the absence of specific HLA-C alleles. J Immuno/ 2002, 169:2818-2822.

91. van der Slik AR, Koeleman BPC, Verduijn W, Bruining GJ, Roep BO, Giphart MJ: KIR in type 1 diabetes: disparate distribution of activating and inhibitory natural killer cell receptors in patients versus HLA-matched control subjects. Diabetes 2003, 52:2639-2642.

92. Takeno M, Shimoyama Y, Kashiwakura J-I, Nagafuchi H, Sakane T, Suzuki N: Abnormal killer inhibitory receptor expression on natural killer cells in patients with Behçet's disease. Rheumatol Int 2004, 24:212-216.

93. Nelson GW, Martin MP, Gladman D, Wade J, Trowsdale J, Carrington M: Cutting edge: heterozygote advantage in autoimmune disease: hierarchy of protection/susceptibility conferred by HLA and killer lg-like receptor combinations in psoriatic arthritis. J Immuno/ 2004, 173:4273-4276.

94. Chan AT, Kollnberger SD, Wedderburn LR, Bowness P: Expansion and enhanced survival of natural killer cells expressing the killer immunoglobulin-like receptor KIR3DL2 in spondylarthritis. Arthritis Rheum 2005, 52:3586-3595.

95. Fusco C, Guerini FR, Nocera G, Ventrella G, Caputo D, Valentino MA, Agliardi C, Gallotti J, Morra VB, Florio C, Clerici M, Lombardi ML: KIRs and their HLA ligands in remitting-relapsing multiple sclerosis. J Neuroimmuno/ 2010, 229:232-237.

96. Pellett F, Siannis F, Vukin I, Lee P, Urowitz MB, Gladman DD: KIRs and autoimmune disease: studies in systemic lupus erythematosus and scleroderma. Tissue Antigens 2007, 69(Suppl 1):106-108.

97. Momot T, Koch S, Hunzelmann N, Krieg T, Ulbricht K, Schmidt RE, Witte T: Association of killer cell immunoglobulin-like receptors with scleroderma. Arthritis Rheum 2004, 50:1561-1565

98. Morandi B, Bramanti P, Bonaccorsi I, Montalto E, Oliveri D, Pezzino G, Navarra M, Ferlazzo G: Role of natural killer cells in the pathogenesis and progression of multiple sclerosis. Pharmacol Res 2008, 57:1-5.

99. Gandhi R, Laroni A, Weiner HL: Role of the innate immune system in the pathogenesis of multiple sclerosis. J Neuroimmuno/ 2010, 221:7-14.

100. Jiang W, Chai NR, Maric D, Bielekova B: Unexpected role for granzyme K in CD56 ${ }^{\text {bright }} \mathrm{NK}$ cell-mediated immunoregulation of multiple sclerosis. $\mathrm{J} / \mathrm{mm}$ muno/ 2011, 187:781-790.

101. Morse RH, Séguin R, McCrea EL, Antel JP: NK cell-mediated lysis of autologous human oligodendrocytes. J Neuroimmunol 2001, 116:107-115.

102. Saikali P, Antel JP, Newcombe J, Chen Z, Freedman M, Blain M, Cayrol R, Prat A Hall JA, Arbour N: NKG2D-mediated cytotoxicity toward oligodendrocytes suggests a mechanism for tissue injury in multiple sclerosis. J Neurosc 2007, 27:1220-1228.

103. Zhang BN, Yamamura T, Kondo T, Fujiwara M, Tabira T: Regulation of experimental autoimmune encephalomyelitis by natural killer (NK) cells. J Exp Med 1997, 186:1677-1687.

104. Matsumoto Y, Kohyama K, Aikawa Y, Shin T, Kawazoe Y, Suzuki Y, Tanuma N: Role of natural killer cells and TCR gamma delta T cells in acute autoimmune encephalomyelitis. Eur J Immuno/ 1998, 28:1681-1688.

105. Xu W, Fazekas G, Hara H, Tabira T: Mechanism of natural killer (NK) cell regulatory role in experimental autoimmune encephalomyelitis. J Neuroimmunol 2005, 163:24-30.

106. Huang D, Shi F-D, Jung S, Pien GC, Wang J, Salazar-Mather TP, He TT, Weaver JT, Ljunggren $H G$, Biron CA, Littman DR, Ransohoff RM: The neuronal chemokine CX3CL1/fractalkine selectively recruits NK cells that modify experimental autoimmune encephalomyelitis within the central nervous system. FASEB J 2006, 20:896-905.

107. Winkler-Pickett R, Young HA, Cherry JM, Diehl J, Wine J, BackT, Bere WE, Mason AT, Ortaldo JR: In vivo regulation of experimental autoimmune encephalomyelitis by NK cells: alteration of primary adaptive responses. $\mathrm{J}$ Immunol 2008, 180:4495-4506.

108. Shi FD, Takeda K, Akira S, Sarvetnick N, Ljunggren HG: IL-18 directs autoreactive $T$ cells and promotes autodestruction in the central nervous system via induction of IFN-gamma by NK cells. J Immuno/ 2000 165:3099-3104.

109. Vollmer TL, Liu R, Price M, Rhodes S, La Cava A, Shi F-D: Differential effects of IL-21 during initiation and progression of autoimmunity against neuroantigen. J Immuno/ 2005, 174:2696-2701.

110. Munschauer FE, Hartrich LA, Stewart CC, Jacobs L: Circulating natural killer cells but not cytotoxic T lymphocytes are reduced in patients with active 
relapsing multiple sclerosis and little clinical disability as compared to controls. J Neuroimmunol 1995, 62:177-181.

111. Takahashi K, Miyake S, Kondo T, Terao K, Hatakenaka M, Hashimoto S, Yamamura T: Natural killer type 2 bias in remission of multiple sclerosis. J Clin Invest 2001, 107:R23-R29.

112. Takahashi K, Aranami T, Endoh M, Miyake S, Yamamura T: The regulatory role of natural killer cells in multiple sclerosis. Brain 2004, 127(Pt 9):1917-1927.

113. Hamann I, Dörr J, Glumm R, Chanvillard C, Janssen A, Millward JM, Paul F, Ransohoff RM, Infante-Duarte C: Characterization of natural killer cells in paired CSF and blood samples during neuroinflammation. J Neuroimmunol 2012, 254:165-169.

114. Bielekova B, Catalfamo M, Reichert-Scrivner S, Packer A, Cerna M, Waldmann TA, McFarland H, Henkart PA, Martin R: Regulatory CD56(bright) natural killer cells mediate immunomodulatory effects of IL-2Ra-targeted therapy (daclizumab) in multiple sclerosis. Proc Natl Acad Sci U S A 2006, 103:5941-5946.

115. Bielekova B, Howard T, Packer AN, Richert N, Blevins G, Ohayon J, Waldmann TA, McFarland HF, Martin R: Effect of anti-CD25 antibody daclizumab in the inhibition of inflammation and stabilization of disease progression in multiple sclerosis. Arch Neurol 2009, 66:483-489.

116. Ahern DJ, Brennan FM: The role of natural killer cells in the pathogenesis of rheumatoid arthritis: major contributors or essential homeostatic modulators? Immunol Lett 2011, 136:115-121.

117. Conigliaro P, Scrivo R, Valesini G, Perricone R: Emerging role for NK cells in the pathogenesis of inflammatory arthropathies. Autoimmun Rev 2011, 10:577-581.

118. Tak PP, Kummer JA, Hack CE, Daha MR, Smeets TJ, Erkelens GW, Meinders AE, Kluin PM, Breedveld FC: Granzyme-positive cytotoxic cells are specifically increased in early rheumatoid synovial tissue. Arthritis Rheum 1994, 37:1735-1743

119. de Matos CT, Berg L, Michaëlsson J, Felländer-Tsai L, Kärre K, Söderström K Activating and inhibitory receptors on synovial fluid natural killer cells of arthritis patients: role of CD94/NKG2A in control of cytokine secretion. Immunology 2007, 122:291-301.

120. Zhang AL, Colmenero P, Purath U, Teixeira de Matos C, Hueber W, Klareskog L, Tarner IH, Engleman EG, Söderström K: Natural killer cells trigger differentiation of monocytes into dendritic cells. Blood 2007, 110:2484-2493.

121. Ren J, Feng Z, Lv Z, Chen X, Li J: Natural killer-22 cells in the synovial fluid of patients with rheumatoid arthritis are an innate source of interleukin 22 and tumor necrosis factor-a. J Rheumatol 2011, 38:2112-2118.

122. Groh V, Bruhl A, El-Gabalawy H, Nelson JL, Spies T: Stimulation of T cell autoreactivity by anomalous expression of NKG2D and its MIC ligands in rheumatoid arthritis. Proc Natl Acad Sci U S A 2003, 100:9452-9457.

123. Aramaki T, Ida H, Izumi Y, Fujikawa K, Huang M, Arima K, Tamai M, Kamachi M, Nakamura H, Kawakami A, Origuchi T,Matsuoka N, Eguchi K: A significantly impaired natural killer cell activity due to a low activity on a per-cell basis in rheumatoid arthritis. Mod Rheumatol 2009, 19:245-252.

124. Wulffraat NM, Rijkers GT, Elst E, Brooimans R, Kuis W: Reduced perforin expression in systemic juvenile idiopathic arthritis is restored by autologous stem-cell transplantation. Rheumatology (Oxford) 2003, 42:375-379

125. Grom AA, Villanueva J, Lee S, Goldmuntz EA, Passo MH, Filipovich A: Natural killer cell dysfunction in patients with systemic-onset juvenile rheumatoid arthritis and macrophage activation syndrome. J Pediatr 2003, 142:292-296.

126. Villanueva J, Lee S, Giannini EH, Graham TB, Passo MH, Filipovich A, Grom AA: Natural killer cell dysfunction is a distinguishing feature of systemic onset juvenile rheumatoid arthritis and macrophage activation syndrome. Arthritis Res Ther 2005, 7:R30-R37.

127. de Jager W, Vastert SJ, Beekman JM, Wulffraat NM, Kuis W, Coffer PJ, Prakken $B J$ : Defective phosphorylation of interleukin- 18 receptor beta causes impaired natural killer cell function in systemic-onset juvenile idiopathic arthritis. Arthritis Rheum 2009, 60:2782-2793.

128. Vastert SJ, van Wijk R, D\&apos; Urbano LE, de Vooght KMK, de Jager W, Ravelli A, Magni-Manzoni S, Insalaco A, Cortis E, van Solinge WW, Prakken BJ, Wulffraat NM, de Benedetti F, Kuis W: Mutations in the perforin gene can be linked to macrophage activation syndrome in patients with systemic onset juvenile idiopathic arthritis. Rheumatology (Oxford) 2010, 49:441-449.

129. Hazen MM, Woodward AL, Hofmann I, Degar BA, Grom A, Filipovich AH, Binstadt BA: Mutations of the hemophagocytic lymphohistiocytosisassociated gene UNC13D in a patient with systemic juvenile idiopathic arthritis. Arthritis Rheum 2008, 58:567-570.

130. Zhang K, Biroschak J, Glass DN, Thompson SD, Finkel T, Passo MH, Binstadt BA, Filipovich A, Grom AA: Macrophage activation syndrome in patients with systemic juvenile idiopathic arthritis is associated with MUNC13-4 polymorphisms. Arthritis Rheum 2008, 58:2892-2896.

131. Lo CKC, Lam QLK, Sun L, Wang S, Ko K-H, Xu H, Wu C-Y, Zheng B-J, Lu L: Natural killer cell degeneration exacerbates experimental arthritis in mice via enhanced interleukin-17 production. Arthritis Rheum 2008, 58:2700-2711.

132. Nilsson N, Bremell T, Tarkowski A, Carlsten H: Protective role of NK1.1 $1^{+}$cells in experimental Staphylococcus aureus arthritis. Clin Exp Immunol 1999, 117:63-69.

133. Wu H-J, Sawaya H, Binstadt B, Brickelmaier M, Blasius A, Gorelik L, Mahmood U, Weissleder R, Carulli J, Benoist C, Mathis D: Inflammatory arthritis can be reined in by CpG-induced DC-NK cell cross talk. J Exp Med 2007, 204:1911-1922.

134. Leavenworth JW, Wang X, Wenander CS, Spee P, Cantor H: Mobilization of natural killer cells inhibits development of collagen-induced arthritis. Proc Natl Acad SciU S A 2011, 108:14584-14589.

135. Söderström K, Stein E, Colmenero P, Purath U, Müller-Ladner U, de Matos CT, Tarner IH, Robinson WH, Engleman EG: Natural killer cells trigger osteoclastogenesis and bone destruction in arthritis. Proc Natl Acad Sci US A 2010, 107:13028-13033.

136. Yuan D, Thet S, Zhou XJ, Wakeland EK, Dang T: The role of NK cells in the development of autoantibodies. Autoimmunity 2011, 44:641-651.

137. Takeda K, Dennert G: The development of autoimmunity in C57BL/6 lpr mice correlates with the disappearance of natural killer type 1-positive cells: evidence for their suppressive action on bone marrow stem cell proliferation, B cell immunoglobulin secretion, and autoimmune symptoms. J Exp Med 1993, 177:155-164.

138. Huang Z, Fu B, Zheng SG, Li X, Sun R, Tian Z, Wei H: Involvement of CD226+ NK cells in immunopathogenesis of systemic lupus erythematosus. J Immunol 2011, 186:3421-3431.

139. Schleinitz N, Chiche L, Guia S, Bouvier G, Vernier J, Morice A, Houssaint E, Harlé J-R, Kaplanski G, Montero-Julian FA, Vély F: Pattern of DAP12 expression in leukocytes from both healthy and systemic lupus erythematosus patients. PLOS ONE 2009, 4:e6264.

140. Hervier B, Beziat V, Haroche J, Mathian A, Lebon P, Ghillani-Dalbin P, Musset L, Debré $P$, Amoura Z, Vieillard V: Phenotype and function of natural killer cells in systemic lupus erythematosus: excess interferon- $\gamma$ production in patients with active disease. Arthritis Rheum 2011, 63:1698-1706.

141. Puxeddu I, Bongiorni F, Chimenti D, Bombardieri S, Moretta A, Bottino C, Migliorini P: Cell surface expression of activating receptors and coreceptors on peripheral blood NK cells in systemic autoimmune diseases. Scand J Rheumatol 2012, 41:298-304

142. Erkeller-Yuksel FM, Lydyard PM, Isenberg DA: Lack of NK cells in lupus patients with renal involvement. Lupus 1997, 6:708-712

143. Riccieri V, Spadaro A, Parisi G, Taccari E, Moretti T, Bernardini G, Favaroni M, Strom R: Down-regulation of natural killer cells and of gamma/delta T cells in systemic lupus erythematosus. Does it correlate to autoimmunity and to laboratory indices of disease activity? Lupus 2000, 9:333-337.

144. Schepis D, Gunnarsson I, Eloranta M-L, Lampa J, Jacobson SH, Kärre K, Berg L: Increased proportion of CD56 bright natural killer cells in active and inactive systemic lupus erythematosus. Immunology 2009, 126:140-146.

145. Green MRJ, Kennell ASM, Larche MJ, Seifert MH, Isenberg DA, Salaman MR: Natural killer cell activity in families of patients with systemic lupus erythematosus: demonstration of a killing defect in patients. Clin Exp Immunol 2005, 141:165-173.

doi:10.1186/ar4232

Cite this article as: Fogel LA, et al:: Natural killer cells in human autoimmune disorders. Arthritis Research \& Therapy 2013, 15:216. 